\title{
ROLL WEAR MODELING USING GENETIC PROGRAMMING - INDUSTRY CASE STUDY
}

\author{
MODELIRANJE OBRABE VALJEV Z GENETSKIM \\ PROGRAMIRANJEM - PRIMER IZ INDUSTRIJE
}

\author{
Miha Kovačič ${ }^{*}$, Andrej Mihevc ${ }^{2}$, Milan Terčelj ${ }^{3}$ \\ 1Štore Steel d.o.o., Železarska cesta 3, 3220 Štore; Institute of Metals and Technology, Lepi pot 11, 1000 Ljubljana; College of Industrial \\ Engineering, Mariborska cesta 2, 3000 Celje, Slovenia \\ 2Štore Steel d.o.o., Železarska cesta 3, 3220 Store, Slovenia \\ ${ }^{3}$ Faculty of Natural Sciences and Engineering, Department of Materials and Metallurgy, Aškerčeva cesta 12, 1000 Ljubljana, Slovenia
}

Prejem rokopisa - received: 2018-05-18; sprejem za objavo - accepted for publication: 2018-12-06

doi:10.17222/mit.2018.104

Štore Steel Ltd. is one of the largest flat spring steel producers in Europe. Using the continuous rolling line (10 stands -6 horizontal, 4 vertical), all the rolled dimensions, including round (more than 80 nominal diameters), flat (more than 650 shapes and dimensions) and square bars (13 different sizes), can be rolled each month. The purpose of the research was to identify the parameters affecting the working roll wear in the hot-rolling process. For this purpose, we collected data during the 2013 annual production on the first stand of the continuous roll mill for rolling of diameters from $\phi 20 \mathrm{~mm}$ to $\phi 58 \mathrm{~mm}$ for which data of the groove shape and surface, roll diameter, contact time, carbon equivalent, rolling temperature and quantity of the rolled material are available. After roll wear-out they are machined using a turning operation. The root cause "why the rolls were machined" was not collected. To evaluate the roll wear-out, the quantity of rolled material before the machining of rolls was used. Prediction of the quantity of rolled material before the machining of rolls was conducted using linear regression and genetic programming. The developed models were validated using the data from 2014. The validation showed that in the case of excluding the fatigue cracks from collected data the prediction could be improved drastically. The results of the research can be used in practice for predicting roll wear and consequently roll maintenance on the basis of rolling schedule quantities.

Keywords: roll wear, hot rolling, prediction, linear regression, genetic programming

Štore Steel d.o.o. je ena izmed največjih proizvajalcev ploščatega, vzmetnega jekla v Evropi. S pomočjo kontinuirane valjarske proge (10 ogrodij - 6 horizontalnih, 4 vertikalne) lahko mesečno izvaljajo vse dimenzije, vključujoč okrogle (80 premerov), kvadratne (13 stranic) in ploščate (več kot 650 oblik in dimenzij) palice. Namen raziskave je bil prepoznati parametre, ki vplivajo na obrabo valjev med vročim valjanjem. V te namene so se v letu 2013 zbirali podatki pri prvem horizontalnem ogrodju kontinuirane valjarske proge pri valjanju okroglih palic premerov od $\phi 20 \mathrm{~mm}$ do $\phi 58 \mathrm{~mm}$ : oblika in površina kalibra, premer valjev, kontaktni čas, ogljikov ekvivalent, temperatura valjanja in količina izvaljanega materiala. Po obrabi valjev se le-ti mehansko obdelajo - postružijo. Pravi razlog za mehansko obdelavo valjev se ni navajal. Za ovrednotenje obrabe valjev smo uporabili količino materiala, ki se je valjal pred mehansko obdelavo valjev. Za napovedovanje količine materiala, ki se je valjal pred mehansko obdelavo valjev, smo uporabili linearno regresijo in genetsko programiranje. Oba razvita modela smo ovrednotili z uporabo podatkov iz leta 2014. Analiza je pokazala, da se zmožnost napovedovanja pri neupoštevanju utrujenostnih napak drastično izboljša. Rezultati so praktično uporabni pri napovedovanju obrabe valjev ter posledično vzdrževanju valjev v skladu s plani valjanja.

Ključne besede: obraba valjev, vroče valjanje, napovedovanje, linearna regresija, genetsko programiranje

\section{INTRODUCTION}

During the hot rolling of long bars the roll with the grooves allows for dimensional changes to the rolled bars. Due to the constant contact between the hot-rolled material and the cooled roll, the surface of the latter gradually wears out. Also, surface cracks can occur due to temperature gradients influenced by thermo-mechanical-tribological rolling conditions (e.g., roll and rolled material, coolant temperature, rolling speed). Consequently, one must determine influences that the rolls have on the surface defects of rolled material. ${ }^{1-5}$ Accordingly, knowing about roll wear is essential.

Practical approaches for roll wear reduction during hot rolling can be classified as:

*Corresponding author e-mail:

miha.kovacic@store-steel.si
- changing existing roll material, ${ }^{6}$

- using roll surface coatings, ${ }^{1,3}$

- using lubricants, $2,4,7,8$

- changing roll geometry (i.e. grooves) $)^{9-12}$

- using different rolling regimes., ${ }^{2,13-16}$

Though there are several well-known mathematical models for roll wear (i.e., Archard, Yasada, Lim and Ashby, Sibakin, Oike, Somers, Tong and Chakko), ${ }^{1,3}$ but none of them can be used practically in an industrial environment, where the specifics of several different steel grades and where different rolling regimes are produced and bound to delivery dates, come into play.

In our extremely flexible industrial environment, the following were analyzed during a one-year period: the influences of groove geometry, its area, roll diameter, contact time, carbon equivalent of rolled material (more than 200 serially produced different steel grades), rolling 
Table 1: Rolls working layer chemical composition

\begin{tabular}{|c|c|c|c|c|c|c|c|}
\hline $\mathrm{C}$ & $\mathrm{Si}$ & $\mathrm{Mn}$ & $\mathrm{P}$ & $\mathrm{S}$ & $\mathrm{Cr}$ & $\mathrm{Ni}$ & $\mathrm{Mo}$ \\
\hline $3.0 \%-3.8 \%$ & $1.0 \%-1.8 \%$ & $0.3 \%-0.8 \%$ & $<0.060 \%$ & $<0.020 \%$ & $0.5 \%-1.2 \%$ & $1.0 \%-3.0 \%$ & $0.1 \%-0.5 \%$ \\
\hline
\end{tabular}

temperature and quantity of the rolled material on the wear of roll of the first stand of the continuous roll mill for long round bars (diameters from $\phi 20 \mathrm{~mm}$ to $\phi 58 \mathrm{~mm}$ ).

In the paper the experimental setup, including the industrial environment and the monitored parameter descriptions, is presented after the introduction. Afterwards, we present the roll wear prediction, represented as a quantity of the rolled material before the machining of rolls, using genetic programming and linear regression. Also, the results and the validation thereof are commented on. Finally, conclusions are drawn and directions for future work are outlined.

\section{MATERIALS AND METHODS}

Štore Steel Ltd. is a small, flexible steel mill where more than 200 steel grades with varying chemical compositions are produced. The scrap is melted in the electric arc furnace. After tapping, the melt is ladle-treated and finally cast using a two-strand continuous caster. The cooled cast billets $(180 \mathrm{~mm} \times 180 \mathrm{~mm})$ are reheated up to $1250{ }^{\circ} \mathrm{C}$ and rolled. After exiting the reheating furnace, the material goes through the descaling device and duo reversible rolling stand with 800 -mm-diameter rolls. The rolled material makes 7 passes. The final rolling diameters achieved using the same rolling stand range from $\phi 95 \mathrm{~mm}$ to $\phi 110 \mathrm{~mm}$.

Before it enters the continuous rolling line with 460 $\mathrm{mm}$ diameter rolls (700 $\mathrm{mm}$ length), the material is rolled using a duo reversible rolling stand with 650 -mm-diameter rolls. After exiting the duo reversible stand, after 5 passes (the last is a by-pass), the material cools down while the rolling temperature is achieved. The temperature is measured using infrared pyrometer. Note that the rolling is conducted without lubrication.

The number of passes using the continuous rolling line:

- $\phi 20-36$ mm: 9 passes,

-

- $\phi 50-58$ mm: 5 passes.

The continuous rolling line (Figure 1) itself consists of a descaling device, 6 horizontal and 4 vertical stands, three hot shears - of which two are used for cutting the first and the last end of the rolled bar, while the third is used for cutting the final dimensions before the material enters the cooling bed.

The continuous rolling line rolls are double-layered rolls made of steel (outer working layer) and nodular cast iron (the core). The working layer chemical composition is presented in Table 1. The same layer consists of pearlite and bainite, depending on the required hardness. The working layer thickness depends on the groove dimensions. In general, $30 \mathrm{~mm}$ is added, on the basis of the grooves' geometry. The core consists basically of pearlite, but within this free cementite and spherical pearlite could be found.

After rolls of the continuous roll mill wear-out, or fatigue cracks occur, they are additionally machined using a turning operation. The machining is conducted in Štore Steel Ltd. After several machining operations, reaching the core layer, the rolls should be replaced by new ones.

\section{Rolling direction

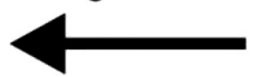

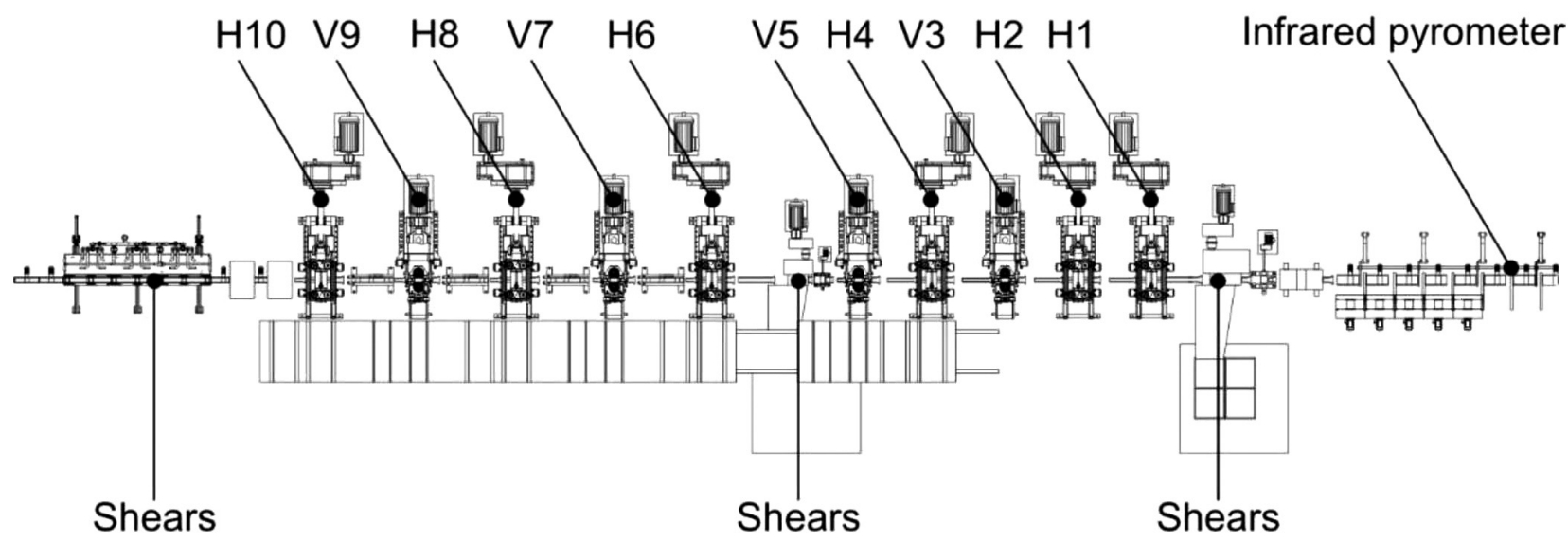

Figure 1: Continuous rolling line 
During 2013 the life of rolls of the first stand (Figure 2) of the continuous roll mill for long round bars (diameters from $\phi 20 \mathrm{~mm}$ to $\phi 58 \mathrm{~mm}$ ) was analyzed. The following parameters were monitored:

- area of the individual groove after machining operation in $\mathrm{mm}^{2}(A G)$,

- diameter of rolls after machining operation in $\mathrm{mm}$ $(D R)$,

- average contact time in s $(T C)$,

- average carbon equivalent in \% (CE),

- average rolling temperature before entering the first rolling stand in ${ }^{\circ} \mathrm{C}(T R)$,

- quantity of rolled material before using machining operation in $\mathrm{kg}\left(Q^{\prime}\right)$.

After the rolls wear out, the removal of the affected area is conducted using a machining process. The removal depth depends on the severity of the affected area. It must be emphasized that detailed information about the root cause for the machining of rolls was not available.

Table 2 shows the reduction of roll diameter $(D R)$ and the area of the grooves on the first stand of the continuous rolling line $(A G)$ during the roll life cycle (before replacement).

Table 2: The area of the individual groove after the machining operation (practical example of roll life cycle)

\begin{tabular}{|c|c|c|c|c|c|}
\hline $\begin{array}{c}\text { Roll } \\
\text { diameter }\end{array}$ & $\begin{array}{c}\mathrm{OV60/1} \\
\left(\mathrm{mm}^{2}\right)\end{array}$ & $\begin{array}{c}\mathrm{OV70/1} \\
\left(\mathrm{mm}^{2}\right)\end{array}$ & $\begin{array}{c}\mathrm{OV70/2} \\
\left(\mathrm{mm}^{2}\right)\end{array}$ & $\begin{array}{c}\mathrm{OV70/3} \\
\left(\mathrm{mm}^{2}\right)\end{array}$ & $\begin{array}{c}\mathrm{OV} 85 / 1 \\
\left(\mathrm{~mm}^{2}\right)\end{array}$ \\
\hline$\phi 460$ & 122859 & 142267 & 148647 & 157561 & 166376 \\
\hline$\phi 419$ & 111327 & 128786 & 134473 & 142394 & 150459 \\
\hline$\phi 418$ & 111046 & 128457 & 134127 & 142024 & 150071 \\
\hline$\phi 416$ & 110484 & 127800 & 133436 & 141284 & 149295 \\
\hline$\phi 413.8$ & 109865 & 127076 & 132675 & 140470 & 148441 \\
\hline$\phi 412.3$ & 109443 & 126583 & 132156 & 139916 & 147859 \\
\hline$\phi 410$ & 108796 & 125827 & 131361 & 139065 & 146966 \\
\hline$\phi 407.3$ & 108037 & 124939 & 130428 & 138066 & 145918 \\
\hline$\phi 405.2$ & 107446 & 124249 & 129702 & 137289 & 145102 \\
\hline$\phi 403$ & 106827 & 123525 & 128941 & 136475 & 144248 \\
\hline$\phi 400.5$ & 106124 & 122703 & 128077 & 135550 & 143278 \\
\hline
\end{tabular}

The contact time is the time between the workpiece entering and exiting the deformation zone. This time is calculated using the following equation:

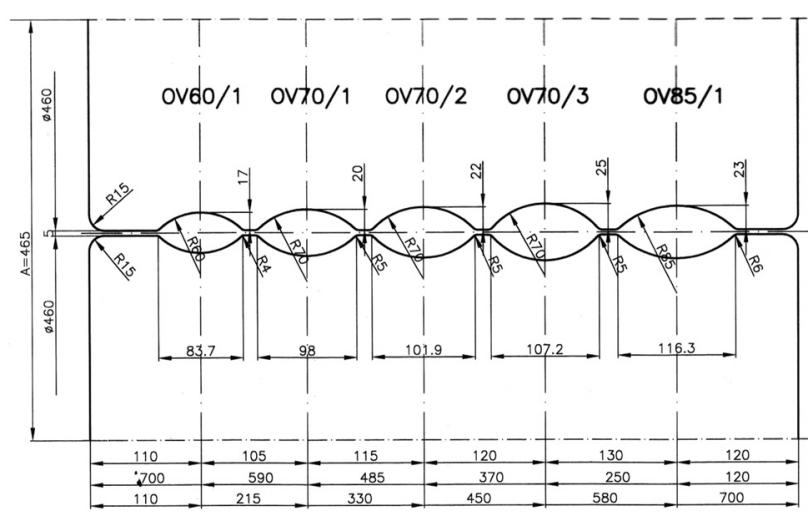

Figure 2: Grooves on the first stand of the continuous rolling line

$$
\begin{aligned}
& t_{\mathrm{c}}=\frac{l}{v}, \text { where } l \text { is contact length } \\
& l=\sqrt{R \cdot \Delta h}, \text { where } R \text { is roll radius, }
\end{aligned}
$$

$\Delta h=h_{0}-h_{1}$, where $h_{0}$ and $h_{1}$ are the effective heights of the ingoing and outgoing workpiece,

$$
v=\frac{v_{r}}{\prod_{i}^{n} R_{-} f_{i}} \text {, where }
$$

$v$ is the roll circumferential speed, $v_{r}$ is the rolling speed and $R_{-} f_{i}$ are the reduction factors for a calculation of the rolling speed at the $i-1$ stand. For instance, the reduction factors for rolling of round bar $\phi 21 \mathrm{~mm}$ using continuous rolling line in Štore for stands H1, H2, V3, H4, V5, H6, V7, H8 and V9 are 1.189, 1.144, 1.286, 1.191, $1.148,1,1,1$ and 1 , respectively.

The following equation for carbon equivalent $(C E)$, a single-number value which covers several influential alloying chemical elements, was used: ${ }^{17}$

$$
\begin{aligned}
& C E=\% C+\frac{\% \mathrm{Mn}+\% \mathrm{Si}}{6}+ \\
& +\frac{\% \mathrm{Cr}+\% \mathrm{Mo}+\% \mathrm{~V}}{5}+\frac{\% \mathrm{Cu}+\% \mathrm{Ni}}{15}
\end{aligned}
$$

\begin{tabular}{|c|c|c|c|c|c|}
\hline $\begin{array}{l}\text { Area of the } \\
\text { individual } \\
\text { groove after } \\
\text { machining } \\
\text { operation in } \\
\mathrm{mm}^{2}(A G)\end{array}$ & $\begin{array}{c}\text { Diameter of } \\
\text { rolls after } \\
\text { machining } \\
\text { operation in } \\
\text { mm }(D R)\end{array}$ & $\begin{array}{c}\text { Average } \\
\text { contact } \\
\text { time in s } \\
(T C)\end{array}$ & $\begin{array}{c}\text { Average } \\
\text { carbon } \\
\text { equivalent in } \\
\%(C E)\end{array}$ & \begin{tabular}{|c|} 
Average \\
rolling \\
temperature \\
before \\
entering the \\
first rolling \\
stand in ${ }^{\circ} \mathrm{C}$ \\
$(T R)$ \\
\end{tabular} & $\begin{array}{l}\text { Quantity of } \\
\text { rolled } \\
\text { material } \\
\text { before using } \\
\text { machining } \\
\text { operation in } \\
\mathrm{kg}\left(Q^{\prime}\right)\end{array}$ \\
\hline 111327 & 419.0 & 0.0506 & 0.699 & 930 & 776725 \\
\hline 134473 & 419.0 & 0.0596 & 0.739 & 930 & 1199800 \\
\hline 128786 & 419.0 & 0.0591 & 0.825 & 930 & 2325295 \\
\hline 142394 & 419.0 & 0.0699 & 0.763 & 930 & 738240 \\
\hline 134473 & 419.0 & 0.0561 & 0.789 & 930 & 356043 \\
\hline 150459 & 419.0 & 0.0626 & 0.715 & 930 & 535983 \\
\hline 111046 & 418.0 & 0.0482 & 0.681 & 930 & 1153125 \\
\hline 134127 & 418.0 & 0.0600 & 0.698 & 930 & 2145300 \\
\hline 128457 & 418.0 & 0.0577 & 0.830 & 930 & 1514790 \\
\hline 142024 & 418.0 & 0.0664 & 0.853 & 930 & 678110 \\
\hline 150071 & 418.0 & 0.0605 & 0.705 & 930 & 456370 \\
\hline 109865 & 413.8 & 0.0505 & 0.666 & 930 & 1369770 \\
\hline 132675 & 413.8 & 0.0588 & 0.752 & 930 & 2210725 \\
\hline 148441 & 413.8 & 0.0564 & 0.709 & 930 & 143935 \\
\hline 139989 & 412.5 & 0.0699 & 0.813 & 930 & 745308 \\
\hline 126649 & 412.5 & 0.0582 & 0.818 & 930 & 2497160 \\
\hline 139989 & 412.5 & 0.0579 & 0.672 & 930 & 232620 \\
\hline 132225 & 412.5 & 0.0590 & 0.825 & 930 & 744396 \\
\hline 147936 & 412.5 & 0.0643 & 0.762 & 930 & 619500 \\
\hline 109499 & 412.5 & 0.0497 & 0.674 & 930 & 1209050 \\
\hline 132225 & 412.5 & 0.0602 & 0.738 & 930 & 1217867 \\
\hline 108796 & 410.0 & 0.0580 & 0.778 & 930 & 1366531 \\
\hline 139065 & 410.0 & 0.0671 & 0.797 & 930 & 716430 \\
\hline 131361 & 410.0 & 0.0608 & 0.838 & 930 & 645393 \\
\hline
\end{tabular}

Selected parameters, collected during the 2013 annual production, are presented in Table $\mathbf{3}$.

Table 3: Selected parameters, collected during the 2013 annual production 


\begin{tabular}{|c|c|c|c|c|c|}
\hline 146966 & 410.0 & 0.0557 & 0.632 & 930 & 159770 \\
\hline 108796 & 410.0 & 0.0492 & 0.683 & 930 & 1136585 \\
\hline 131361 & 410.0 & 0.0597 & 0.735 & 930 & 3848941 \\
\hline 124939 & 407.3 & 0.0580 & 0.781 & 930 & 1134305 \\
\hline 138066 & 407.3 & 0.0697 & 0.822 & 930 & 594478 \\
\hline 130428 & 407.3 & 0.0610 & 0.771 & 930 & 363901 \\
\hline 145918 & 407.3 & 0.0685 & 0.638 & 930 & 103334 \\
\hline 108037 & 407.3 & 0.0494 & 0.634 & 930 & 1420125 \\
\hline 130428 & 407.3 & 0.0587 & 0.724 & 930 & 2005551 \\
\hline 124249 & 405.2 & 0.0568 & 0.798 & 890 & 1333585 \\
\hline 137289 & 405.2 & 0.0675 & 0.843 & 890 & 804196 \\
\hline 129702 & 405.2 & 0.0582 & 0.765 & 890 & 544345 \\
\hline 145102 & 405.2 & 0.0616 & 0.693 & 890 & 603295 \\
\hline 107446 & 405.2 & 0.0511 & 0.654 & 890 & 1127800 \\
\hline 129702 & 405.2 & 0.0591 & 0.728 & 890 & 1956695 \\
\hline 123525 & 403.0 & 0.0575 & 0.858 & 930 & 1637455 \\
\hline 136475 & 403.0 & 0.0640 & 0.856 & 930 & 370090 \\
\hline 128941 & 403.0 & 0.0546 & 0.798 & 930 & 253489 \\
\hline 144248 & 403.0 & 0.0597 & 0.741 & 930 & 179320 \\
\hline
\end{tabular}

\section{RESULTS}

On the basis of the collected data (Table 4), the prediction of the quantity of rolled material before the machining of the rolls was conducted using linear regression and genetic programming. For the fitness function $\Delta$ average relative deviation between predicted and experimental data was selected. It is defined as:

$$
\Delta=\frac{\sum_{i=1}^{n} \frac{\left(Q_{i}-Q_{i}^{\prime}\right)}{Q_{i}^{\prime}}}{n}
$$

where $n$ is the size of monitored data and $Q^{\prime}{ }_{i}$ and $Q_{i}$ are the actual and the predicted quantities of the rolled material before the machining of rolls, respectively.

\subsection{Linear regression prediction}

On the basis of the linear regression results, it is possible to conclude that the model does not predict in a significant manner the quantity of rolled material before

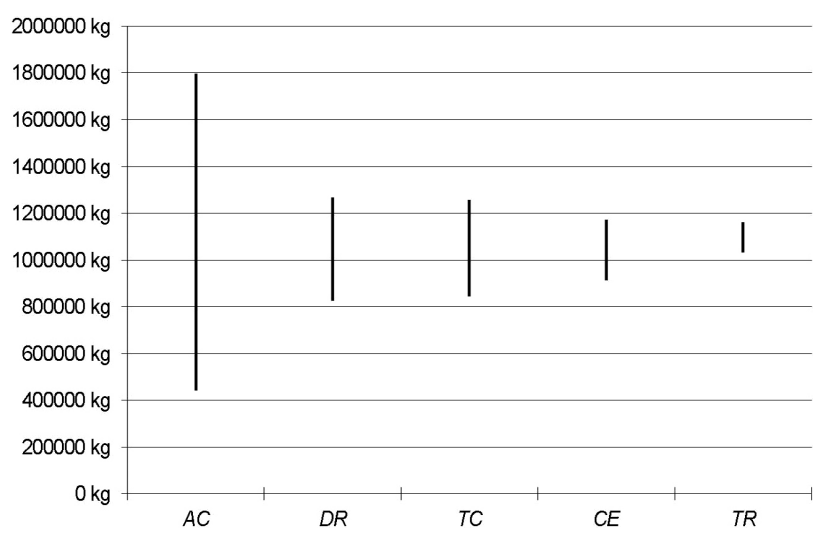

Figure 3: Calculated influences of individual parameters on the quantity of rolled material before the machining of rolls using a linear-regression model $[\mathrm{kg}]$ the machining of the rolls ( $p>0.05$, ANOVA) and that only $19.43 \%$ of the total variances can be explained by the independent variables' variances (R-square). The only significantly influential parameter $(\mathrm{p}<0.05)$ is the area of the individual groove after machining $(A G)$. The linear-regression model is:

$$
\begin{aligned}
& \mathrm{Q}=-31.45 \cdot \mathrm{AG}+27377 \cdot \mathrm{DR}+18891118 \cdot \mathrm{TC}+ \\
& +1140389 \cdot \mathrm{CE}-3227 \cdot \mathrm{TR}+5072217
\end{aligned}
$$

Its relative deviation from the experimental data is $71.10 \%$. The calculated influences of the individual parameters (individual variables) on the quantity of rolled material before the machining of the rolls are presented in Figure 3. It is possible, on the basis of the same figure, to conclude that the area of the individual groove after machining is most influential.

\subsection{Genetic programming prediction}

Genetic programming is probably the most general evolutionary optimization method. ${ }^{18-20}$ Evolutionary optimization methods mimic the natural evolution of living things and can be used for solving different problems (see, for example ${ }^{21-24}$ ). The organisms in genetic programming that undergo adaptation are in fact mathematical expressions (models) for predicting the quantity of the rolled material before the machining of rolls. The models - that is, computer programs - consist of the selected function (i.e., basic arithmetical functions) and terminal genes (i.e., independent input parameters, and random floating-point constants). Typical function genes are: addition (+), subtraction (-), multiplication $(*)$ and division (/), and terminal genes (e.g. $x, y, z$ ).

Random computer programs for calculating the various forms and lengths are generated by means of the selected genes at the beginning of the simulated evolution. The varying of the computer programs is conducted

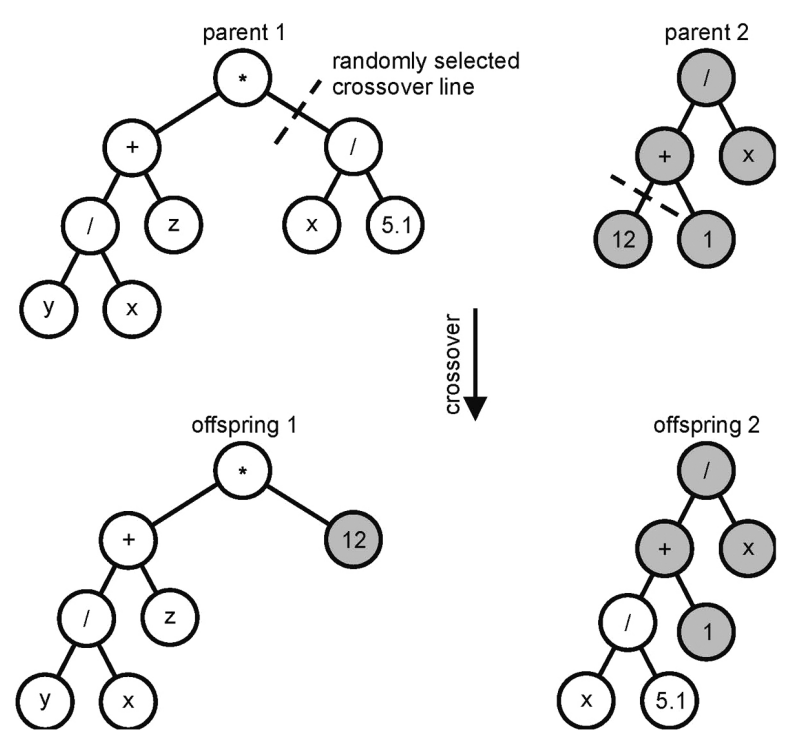

Figure 4: Crossover operation (out of two parental organisms the off springs with randomly distributed genetic material are evolved) 


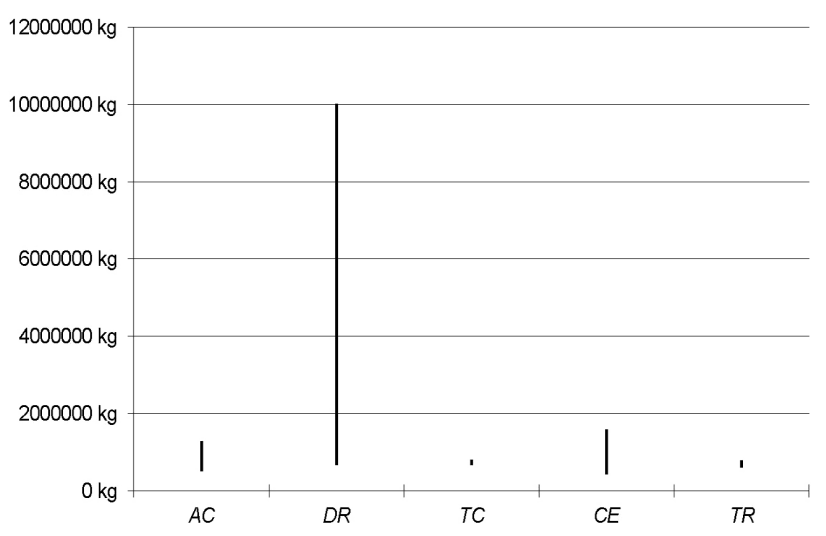

Figure 5: Calculated influences of individual parameters on the quantity of rolled material before the machining of the rolls using the genetic programming model $[\mathrm{kg}]$

with genetic operations (e.g., crossover, mutation) during several iterations, called generations. The crossover operation is presented in Figure 4. After the completion of the variation of the computer programs a new generation is obtained. Each result obtained from an individual program from a generation is compared with the experimental data. The process of changing and evaluating the organisms is repeated until the termination criterion of the process is fulfilled.
In-house genetic programming system, programmed using AutoLISP, which is integrated in AutoCAD - commercial computer-aided design software, was used. ${ }^{25-27}$ Its settings were:

- size of the population of organisms: 1000 ,

- maximum number of generations: 100 ,

- reproduction probability: 0.4 ,

- crossover probability: 0.6,

- maximum permissible depth in the creation of the population: 6 ,

- maximum permissible depth after the operation of crossover of two organisms: 10,

- smallest permissible depth of organisms in generating new organisms: 2.

The genetic operations of reproduction and crossover were used. For the selection of organisms the tournament method with tournament size 7 was used.

The AutoLISP based in-house genetic programming system was run 100 times in order to develop 100 independent civilizations. Each run lasted approximately 1 min on a I7 Intel processor and 8 GB of RAM.

The best mathematical model obtained from 100 runs of the genetic programming system is:

$$
\begin{aligned}
& Q= \\
& \frac{1}{A G \cdot C E\left(-\frac{1}{C E}+\frac{T R}{D R}\right)} T R(D R+C T \cdot D R+(C T+D R+2 C T \cdot D R)+ \\
& \frac{\left(-C E+\frac{T R}{C E^{2} \cdot D R}\right)\left(-C T+\frac{T R}{C E\left(\frac{C E^{2}}{C T}+D R\right)}\right)}{C E-\frac{2}{D R}+\frac{T R}{D R}-\frac{T R}{C E \cdot D R}}+C T\left(D R+C T\left(C T+D R+2 T R+\frac{-C E+\frac{T R}{C E \cdot D R}}{C T}\right)\right)(-2 A G- \\
& D R-T R+C E \cdot D R(C E \cdot D R+T R)+\frac{T R\left(-T R+\frac{T R}{D R}\right)\left(C T+0.161\left(-C E^{2}+\frac{T R}{D R}\right)\right)}{C E+\frac{C E}{C T}}+ \\
& \frac{\left(C E \cdot C T(D R+T R)+\frac{D R-C E}{-C E+\frac{T R}{D R}}\right)\left(C T \cdot D R+\frac{2.072\left(2 C T \cdot D R-C E+\frac{T R}{D R}\right)}{-C E^{2}+\frac{T R}{D R}}\right)}{-C E+\frac{T R}{D R}}+2.072\left(\frac{C E}{D R(D R-T R)}-2 T R\left(\frac{T R}{D R}-\frac{1}{C E}\right)^{2}+\right. \\
& \left.\left.\frac{\left(\frac{C E}{D R}-T R\right) T R\left(C T+\frac{-C E+\frac{T R}{C E \cdot D R}}{T R}\right)}{C E+\frac{C E^{2}}{C T}}+\frac{D R\left(\frac{C E+2 C T \cdot D R}{-\frac{1}{C E}+\frac{T R}{D R}+\frac{C E+C T \cdot D R}{-C T+\frac{T R}{C E \cdot D R}}}\right)}{-C E+\frac{1}{D R^{2}}+\frac{T R}{D R}}\right)\right)
\end{aligned}
$$


Its relative deviation from the experimental data is $43.93 \%$, which is 1.62 -times better than a linear regression model. The calculated influences of the individual parameters (individual variables) on the quantity of rolled material before the machining of the rolls are presented in Figure 5. Based on the same figure it is possible to conclude that the roll diameter after machining is the most influential parameter.

\section{DISCUSSION}

Based on linear regression and genetic programming modeling we can conclude:

- both models' performances are relatively low,

- the most influential parameters (area of the individual groove after machining operation, diameter of the rolls after machining operation) depend on the machining of the rolls and, consequently, additional data and a precise description of the root cause for machining of rolls are needed.

Accordingly, additional data was gathered during the period of an additional year, 2014 (Table 4). In all 16 cases the rolls were machined only due to their having worn out. No fatigue cracks were noted during the year 2014.

Table 4: Selected parameters, collected during the 2014 annual production

\begin{tabular}{|c|c|c|c|c|c|}
\hline $\begin{array}{c}\text { Area of the } \\
\text { individual } \\
\text { groove after } \\
\text { machining } \\
\text { operation in } \\
\mathrm{mm}^{2}(A G)\end{array}$ & $\begin{array}{c}\text { Diameter of } \\
\text { rolls after } \\
\text { machining } \\
\text { operation in } \\
\text { mm }(D R)\end{array}$ & $\begin{array}{c}\text { Average } \\
\text { contact } \\
\text { time in s } \\
(T C)\end{array}$ & $\begin{array}{c}\text { Average } \\
\text { Average } \\
\text { carbon } \\
\text { rolling } \\
\%(C E)\end{array}$ & $\begin{array}{c}\text { Quantity of } \\
\text { temperature } \\
\text { before } \\
\text { beforing the } \\
\text { first rolling } \\
\text { stand in } \\
(T R)\end{array}$ & $\begin{array}{c}{ }^{\circ} \mathrm{C} \text { Ced } \\
\text { material } \\
\text { before using } \\
\text { machining } \\
\text { operation in } \\
\text { kg }\left(Q^{\prime}\right)\end{array}$ \\
\hline 142268 & 460.0 & 0.0612 & 0.812 & 930 & 946000 \\
\hline 122859 & 460.0 & 0.0538 & 0.687 & 930 & 1196360 \\
\hline 148647 & 460.0 & 0.0632 & 0.741 & 930 & 2146800 \\
\hline 141347 & 457.2 & 0.0617 & 0.853 & 930 & 33195370 \\
\hline 165290 & 457.2 & 0.0613 & 0.651 & 930 & 6043100 \\
\hline 147679 & 457.2 & 0.0633 & 0.745 & 930 & 23035450 \\
\hline 121341 & 454.6 & 0.0516 & 0.682 & 930 & 14102600 \\
\hline 146781 & 454.6 & 0.0628 & 0.725 & 930 & 17868800 \\
\hline 140492 & 454.6 & 0.0621 & 0.767 & 930 & 30325250 \\
\hline 146781 & 454.6 & 0.0619 & 0.755 & 930 & 9038860 \\
\hline 164280 & 454.6 & 0.0677 & 0.628 & 930 & 6610820 \\
\hline 139637 & 452.0 & 0.0613 & 0.812 & 930 & 16725950 \\
\hline 120609 & 452.0 & 0.0517 & 0.630 & 930 & 12177050 \\
\hline 145882 & 452.0 & 0.0623 & 0.767 & 930 & 29562300 \\
\hline 138749 & 449.3 & 0.0609 & 0.839 & 930 & 11691900 \\
\hline 144948 & 449.3 & 0.0624 & 0.787 & 930 & 20959950 \\
\hline
\end{tabular}

The relative deviations from the experimental data of the linear regression (Equation (7)) and genetically (Equation (8)) developed model are $55.72 \%$ and $31.56 \%$, respectively. The improvement in performance of both models for the quantity of rolled material before the machining of rolls suggests that the previously gathered data (from the year 2013) should be filtered out from instantaneous root causes (e.g., fatigue cracks) and only roll wear out should be taken into account.

\section{CONCLUSIONS}

Štore Steel Ltd. is a small, flexible steel mill where more than 200 steel grades with varying chemical compositions are produced. The material is rolled using a continuous rolling line, which rolls are double layered and made of steel (outer working layer) and nodular cast iron (the core).

After roll wear-out - that is, after the rolls became worn out - they are machined using a turning operation.

In the research the life of rolls of the first stand (Figure 2) of the continuous roll mill for long round bars (diameters from $\phi 20 \mathrm{~mm}$ to $\phi 58 \mathrm{~mm}$ ) was analyzed for 2013. The following parameters were monitored:

- area of the individual groove after machining operation in $\mathrm{mm}^{2}$,

- diameter of rolls after machining operation in mm,

- average contact time in s,

- average carbon equivalent in \%,

- average rolling temperature before entering the first rolling stand in ${ }^{\circ} \mathrm{C}$,

- quantity of rolled material before using machining operation in $\mathrm{kg}$.

On the basis of the collected data (Table 3), the prediction of the quantity of rolled material before the machining of rolls was conducted using linear regression and genetic programming. For genetic programming, an in-house system, programmed using AutoLISP, was used. For the fitness function average relative deviation between predicted and experimental data was selected.

The relative deviations from experimental data of linear regression and genetically developed model are $71.10 \%$ and $43.39 \%$, respectively. The genetically developed model outperformed the linear regression model by 1.62-times. Nevertheless, both models have relatively poor performance.

Additionally, both models were validated using additionally gathered data from 2014 , but in this case the data without fatigue cracks were used.

The relative deviations from the experimental data of linear regression and genetically developed model are $55.72 \%$ and $31.56 \%$, respectively. The drastically improved performance of both models can be attributed to filtering the data - the data regarding machining of the rolls due to fatigue cracks was removed, which also indicates that both models can be accordingly developed again.

In the future only data related to roll wear out will be gathered. Consequently, the relatively precise prediction of roll wear and roll maintenance, based on the rolling schedule quantities, will be possible. It must also be emphasized that the adjusted methodology can be used in various rolling mill environments. 


\section{Acknowledgment}

The authors would like to thank Professor Jason Blake for proofreading, which greatly helped the readability of the paper.

\section{REFERENCES}

${ }^{1}$ C. Bataille, E. Luc, M. Bigerelle, R. Deltombe, M. Dubar, Rolls wear characterization in hot rolling process, Tribol. Int., 100 (2016), doi:10.1016/j.triboint.2016.03.012

${ }^{2}$ D. Strasser, M. Bergmann, B. Smeulders, D. Paesold, K. Krimpelstätter, P. Schellingerhout, A. Kainz, K. Zeman, A novel modelbased approach for the prediction of wear in cold rolling, Wear, 376-377 (2017), doi:10.1016/j.wear.2016.12.056

${ }^{3}$ S. Spuzic, K. N. Strafford, C. Subramanian, G. Savage, Wear of hot rolling mill rolls: an overview, Wear, 176 (1994) 2, doi:10.1016/ 0043-1648(94)90155-4

${ }^{4}$ X. Yu, Z. Jiangad, J. Zhao, D. Wei, J. Zhou, C. Zhoud, Q. Huang, The role of oxide-scale microtexture on tribological behaviour in the nanoparticle lubrication of hot rolling, Tribol. Int., 93 (2016), doi:10.1016/j.triboint.2015.08.049

${ }^{5}$ M. Nilsson and M. Olsson, Microstructural, mechanical and tribological characterisation of roll materials for the finishing stands of the hot strip mill for steel rolling, Wear, 307 (2013) 1-2, doi:10.1016/j.wear.2013.09.002

${ }^{6}$ P. Andersson, J. Levén, and B. Hemming, Hot rolling tests with steel bars and silicon nitride rolls, J. Mater. Process. Technol., 209 (2009) 2, doi:10.1016/j.jmatprotec.2008.02.069

${ }^{7}$ Y. Bao, J. Sun, and L. Kong, Effects of nano-SiO 2 as water-based lubricant additive on surface qualities of strips after hot rolling, Tribol. Int., 114 (2017), doi:10.1016/j.triboint.2017.04.026

${ }^{8}$ X. Wenzhen, Z. Jingwei, W. Hui, Z. Xianming, Z. Xiaoming, X. Jianzhong, J. Sihai, J. Zhengyi, Effects of oil-in-water based nanolubricant containing TiO 2 nanoparticles in hot rolling of 304 stainless steel, Procedia Eng., 207 (2017), doi:10.1016/j.proeng. 2017.10.901

${ }^{9}$ R. Servin-Castañeda, A. M. Garcia-Lara, R. D. Mercado-Solís, C. A. Vega-Lebrun, Development of mathematical model for control wear in backup roll for hot strip mill, J. Iron Steel Res. Int., 21 (2014) 1, doi:10.1016/S1006-706X(14)60008-X

${ }^{10} \mathrm{R}$. Wang et al., Strip shape control capability of hot wide strip rolling mills, J. Univ. Sci. Technol. Beijing, Miner. Metall. Mater., 15 (2008) 1, doi:10.1016/S1005-8850(08)60018-3

${ }^{11}$ J. G. Lenard, Primer on Flat Rolling, $2^{\text {nd }}$ ed., Department of Mechanical and Mechatronics Engineering, University of Waterloo, Ontario 2014, 31-37 (Roll design), doi:10.1016/B978-0-08-0994185.00003-2

${ }^{12}$ X. B. Ma, D. C. Wang, H. M. Liu, C. C. Wen, Y. Zhou, Large concave roll technology for hot rolled silicon steel, Ironmak. Steelmak. 45 (2018) 1, doi:10.1080/03019233.2016.1240841
${ }^{13}$ J. Mian, L. Xuejun, W. Jigang, W. Guangbin, A precision on-line model for the prediction of thermal crown in hot rolling processes, Int. J. Heat Mass Transf., 78 (2014), doi:10.1016/j.ijheatmasstransfer. 2014.07.061

${ }^{14}$ M. Stürmer, J. Dagner, P. Manstetten, H. Köstler, Real-time simulation of temperature in hot rolling rolls, J. Comput. Sci., 5 (2014) 5 , doi:10.1016/j.jocs.2014.04.003

${ }^{15}$ X. Cheng, Z. Jiang, J. Zhao, D. Wei, L. Hao, Investigation of oxide scale on ferritic stainless steel B445J1M and its tribological effect in hot rolling, Wear, 338-339 (2015), doi:10.1016/j.wear.2015.06.014

${ }^{16} \mathrm{Y}$. Fu, H. Yu, Application of mathematical modeling in two-stage rolling of hot rolled wire rods, J. Mater. Process. Technol., 214 (2014) 9, doi:10.1016/j.jmatprotec.2014.04.017

${ }^{17}$ M. Bruneau, C.-M. Uang, R. Sabelli, Ductile Design of Steel Structures, $2^{\text {nd }}$ ed., McGraw-Hill Professional, 2011

${ }^{18}$ J. R. Koza, Genetic Programming: On the Programming of Computers by Means of Natural Selection, MIT Press, Cambridge, MA, USA, 1992

${ }^{19}$ J. R. Koza, Genetic Programming II: Automatic Discovery of Reusable Programs, MIT Press, Cambridge, MA, USA, 1994

${ }^{20}$ K. John, F. H. Bennett III, D. Andre, M. A. Keane, Genetic Programming III: Darwinian Invention and Problem Solving, Morgan Kaufmann Publishers Inc., San Francisco 1999

${ }^{21}$ M. Sekulić, V. Pejić, M. Brezočnik, M. Gostimirović, M. Hadžistević, Prediction of surface roughness in the ball-end milling process using response surface methodology, genetic algorithms, and grey wolf optimizer algorithm, Adv. Prod. Eng. Manag., 13 (2018) 1, doi:10.14743/apem2018.1.270

${ }^{22}$ L. Wang, X. Zhu, Z. Xie, Container assignment optimization considering overlapping amount and operation distance in rail-road transshipment terminal, Adv. Prod. Eng. Manag., 12 (2017) 4, doi:10.14743/apem2017.4.264

${ }^{23}$ P. D. Dubrovski, M. Brezocnik, Porosity and nonwoven fabric vertical wicking rate, Fibers Polym., 17 (2016) 5, doi:10.1007/s12221016-6347-5

${ }^{24}$ J. Gotlih, M. Brezočnik, J. Balič, T. Karner, B. Razboršek, K. Gotlih, Determination of accuracy contour and optimization of workpiece positioning for robot milling, Adv. Prod. Eng. Manag., 12 (2017) 3, doi:10.14743/apem2017.3.254

${ }^{25}$ M. Kovačič, F. Dolenc, Prediction of the natural gas consumption in chemical processing facilities with genetic programming, Genet. Program. Evolvable Mach., (2016), doi:10.1007/s10710-016-9264-x

${ }^{26}$ M. Kovačič, Modeling of total decarburization of spring steel with genetic programming, Mater. Manuf. Process., 30 (2014) 4, doi:10.1080/10426914.2014.961477

${ }^{27}$ M. Kovačič, B. Šarler, Genetic programming prediction of the natural gas consumption in a steel plant, Energy, 66 (2014), doi:10.1016/j.energy.2014.02.001 